\title{
PENGARUH KEDALAMAN TERHADAP PRODUKTIVITAS PRIMER DAN DENSITAS ZOOXANTHELLAE PADA KARANG DOMINAN DI PULAU CEMARA KECIL, KARIMUNJAWA
}

\author{
The Influence Of Depth to Primary Productivity and Density of Zooxanthellae on Coral Dominant in Cemara Kecil \\ Island, Karimunjawa
}

\author{
Lavia Lakastri, Pujiono Wahyu Purnomo*), Max R Muskananfola
}

Program Studi Manajemen Sumberdaya Perairan, Departemen Sumberdaya Akuatik

Fakultas Perikanan dan Ilmu Kelautan, Universitas Diponegoro

J1. Prof. Soedarto, SH. Tembalang, Semarang, Jawa Tengah - 50275, Telp/Fax +6224 7474698

Email : lavialakastri@gmail.com

\begin{abstract}
ABSTRAK
Pulau Cemara Kecil merupakan salah satu pulau yang dijadikan tujuan wisata di Kepulauan Karimunjawa. Terumbu karang merupakan ekosistem pesisir yang memiliki produktivitas tinggi. Nitrat merupakan nutrien sebagai salah satu faktor penentu terpeliharanya produktivitas perairan. Penelitian ini mempelajari perbedaan jumlah sel zooxanthellae yang berpengaruh terhadap nilai produktivitas primernya dan kandungan nitrat yang diserap terhadap perbedaan kedalaman. Tujuan penelitian ini untuk mengetahui perbedaan produktivitas primer bersih (NPP) ekosistem terumbu karang, kandungan nitrat dan densitas zooxanthellae pada kedalaman 1 meter dan 5 meter. Penelitian ini dilaksanakan di Pulau Cemara Kecil pada bulan Maret 2018 dengan metode deskriptif. Hasil penelitian yang diperoleh jenis karang yang dominan adalah Acropora sp. (26,58\%) dan Porites sp (40,38\%) dengan tutupan karang hidup pada kedalaman 1 meter $(70,5 \%)$ kategori baik, kedalaman 5 meter $(76,83 \%)$ kategori sangat baik. Terdapat perbedaan yang signifikan (sig.) pada densitas zooxanthellae $(\operatorname{sig}=0,02)$ dan NPP $(\operatorname{sig}=0,01)$ di kedalaman 1 meter dan 5 meter pada kedua jenis karang. Perbedaan yang kurang signifikan pada konsentrasi nitrat $(\mathrm{sig}=0,395)$ pada kedua kedalaman. Nilai densitas Zooxanthellae dan NPP lebih tinggi pada kedalaman 1 meter dibandingkan kedalaman 5 meter. Kedalaman mempengaruhi jumlah sel zooxanthellae pada karang sehingga akan berpengaruh terhadap produktivitas primer yang dihasilkan. Penyerapan kandungan nitrat oleh zooxanthellae berbeda dipengaruhi oleh faktor fisika kimia lingkungan.
\end{abstract}

Kata Kunci : Karang, Produktivitas Primer, Nitrat, Densitas Zooxanthellae, Pulau Cemara Kecil

\begin{abstract}
Pulau Cemara Kecil is one of the island used as a tourist destination in Karimunjawa. Coral reef are coastal ecosystems that have high productivity. Nitrate is a nutrient as a determining factor for the preservation of marine productivity, nutrients becomes an important factor. This research will study the differences in zooxanthellae cells that effected on their primary productivity value and nitrate absorbed by the depth difference. The purpose of this research is to know the differences of coral reef Net Primary Productivity (NPP), nitrate concentration and density of zooxanthellae at depth of 1 meter and 5 meter. This study was conducted in Cemara Kecil Island on March 2018, with descriptive method. The research results obtained are the dominant species of coral Acropora sp. (26,58\%) and Porites sp. (40,38\%) with living coral cover at a depth of 1 meter (70,5\%) categories are good, the depth of 5 meter (76,83\%) categories are very good. There is a significant difference (sig) on the density of zooxanthellae ( sig =0,03) and NPP (sig =0,01) at a depth of 1 meter and 5 meters on both types of coral. Less significant differences in the concentration of nitrates (sig = 0,395) on both the depth. Zooxanthellae densities values higher than NPP at a depth of 1 meter compared to a depth of 5 meters. Depth affect the density of zooxanthellae on corals so influential is also against the resulting primary productivity. Absorption of different content of nitrate by zooxanthellae are influenced b factors of chemical-physics environment.
\end{abstract}

Keywords : Coral, Primary Productivity, Nitrate, Density of zooxanthellae, Cemara Kecil Island

*) Penulis Penanggungjawab

${ }^{\circledR}$ Copyright by Management of Aquatic Resources (MAQUARES)

440 


\section{PENDAHULUAN}

Ekosistem. terumbu karang merupakan ekosistem yang subur dan paling produktif di lautan karena kemampuannya untuk menahan nutrien (Dahuri et al., 2011). Terumbu karang sangat beragam jenisnya dan memegang peranan penting dalam menjaga keseimbangan ekosistem. Indnesia memiliki luas terumbu karang sekitar $16 \%$ dari terumbu karang dunia (Sayekti et al., 2017). Ekosistem terumbu karang mempunyai fungsi ekologis yaitu sebagai habitat untuk berkembang biak, pengasuhan, mencari makan dan berlindung bagi biota lain. Terumbu karang juga mempunyai fungsi melindungi pantai dari hempasan ombak dan arus laut. Selain itu keindahan alam laut dan terumbu karang sendiri dapat meningkatkan taraf hidup masyarakat sebagai daerah pariwisata bahari (Nababan et al., 2015).

Zooxanthellae merupakan kelompok dinoflagellata fototropik yang umumnya terdapat sebagai endosimbion pada beberapa invertebrata laut (Purnomo et al., 2011). Zooxanthellae dapat melakukan proses fotosintesis karena karang membutuhkan $\mathrm{O}_{2}$ dan zat-zat makanan dari hasil fotosintesis yang dilakukan oleh zooxanthellae (Romimohtarto dan Juwana, 2001). Algae ini dapat membantu mengawetkan unsur hara dengan cara mengakumulasi sisa - sisa metabolisme dari binatang induk (karang). Unsur hara ini, kemudian dimanfaatkan oleh zooxanthellae terutama apabila perairan di sekitarnya miskin akan unsur hara (Supriharyono, 2007). Ketersediaan unsur hara yang cukup akan mempengaruhi berlangsungnya proses fotosintesis oleh fitoplankton. Unsur $\mathrm{N}$ dan $\mathrm{P}$ sering dijadikan faktor pembatas di dalam suatu perairan karena kedua unsur ini dibutuhkan oleh zooxanthellae dalam jumlah besar. Namun bisa kedua unsur tersebut ketersediannya dihabitat bersangkutan dibawah kebutuhan minimum, akibatnya pertumbuhan atau populasi zooxanthellae akan menurun (Mustofa, 2015).

Kepulauan Karimunjawa sebagai Taman nasional telah cukup dikenal sebagai daerah tujuan wisata bawah laut di Propinsi Jawa Tengah (Dinas Kelautan dan Perikanan Kabupaten Jepara, 2008). Tiap tahunnya kondisi terumbu karang semakin menurun akibat banyaknya aktifitas manusia. Kondisi yang dapat terjadi antara lain seperti kerusakan terumbu karang akibat limbah dan sampah rumah tangga (Gustiani dan Ilahude, 2012). Rusaknya terumbu karang dapat mengakibatkan terganggunya fungsi-fungsi ekologis terumbu karang yang sangat penting. Selain berperan sebagai pelindung pantai dari hempasan ombak dan arus kuat, terumbu karang juga mempunyai nilai ekologis sebagai habitat, tempat mencari makanan, tempat asuhan dan tumbuh besar, serta tempat pemijahan bagi berbagai biota laut (Amin, 2012).

Tujuan dari penelitian ini adalah mengetahui perbedaan terhadap densitas zooxanthellae, produktivitas primer dan kandungan nitrat terhadap kedalaman, juga korelasi antara ketiga variabel tersebut.

\section{MATERI DAN METODE PENELITIAN}

\section{A. Materi Penelitian}

Materi yang digunakan dalam penelitian ini adalah zooxanthellae, nitrat dan produktivitas primer pada polip karang dominan, dan beberapa variabel kualitas air. Alat yang digunakan dalam penelitian ini meliputi alat pengambilan sampel, alat pengukuran parameter kimia \& fisika dan alat uji laboratorium. Untuk alat pengambilan sampel meliputi : rol meter, seperangkat alat selam, termometer, refraktormeter, tang, dan GPS, cool box, kamera bawah air, dan alat tulis. Untuk alat pengukuran parameter kimia \& fisika meliputi : refraktometer, $\mathrm{pH}$ Paper, termometer,. Untuk alat uji laboratorium meliputi: centrifuge, haemocytometer, mikroskop optic lab, spektrofotometer, pipet tetes, botol sampel 300 $\mathrm{ml}$, botol BOD gelap $250 \mathrm{ml}$ dan BOD terang $250 \mathrm{ml}$, zipper bag, mortal dan alu

\section{B. Metode Penelitian}

Metode yang digunakan dalam penelitian ini adalah metode deskriptif, dengan tujuan untuk mengetahui deskripsi dan gambaran dari suatu objek pengamatan dan dapat menjelaskan perkembangan yang terjadi pada kondisi pengamatan. Pengambilan Sampel

Penelitian ini dilaksanakan pada 10 - 22 Maret 2018. Pengambilan sampel dilakukan satu kali di Pulau Cemara Kecil, Karimunjawa. Lokasi pengambilan sampel dilakukan di dua kedalaman 1 meter dan 5 meter, dimana masingmasing kedalaman diambil dua jenis karang dominan dengan dua kali pengulangan. Kedalaman 1 meter diambil dengan jarak 50 meter dari bibir pantai dan kedalaman 5 meter diambil dengan jarak 200 meter dari bibir pantai. Variabel pH, debit, dan DO diukur langsung saat pengambilan sampel, sedangkan nitrat dan densitas zooxanthellae diukur di laboratorium.

\section{Pengukuran Kondisi Terumbu Karang}

Pengukuran kualitas terumbu karang bertujuan untuk melihat kondisi terumbu karang pada lokasi penelitian dan mengetahui genus apa yang mendominasi pada ekosistem tersebut. Pengukuran kualitas menggunakan metode Line Transect. Menurut English et al., (1997) rumus yang digunakan untuk menghitung tutupan karang adalah sebagai berikut :

Keterangan :

$$
\mathrm{C}=\frac{L i}{L} \times 100 \% \text {. }
$$

$\mathrm{C}$ :Persentase penutupan terumbu karang

$\mathrm{Li}$ :Total penutupan karang

$L \quad$ :Panjang intercept koloni karang yang dilewati garis transek

\section{Perhitungan Produktivitas Primer pada Karang}

Pengukuran produktivitas primer dengan cara mengambil air sampel menggunakan botol BOD gelap dan terang, kemudian dimasukkan kedalam plastik zipper yang sudah berisi spesimen karang. Botol winkler tersebut diinkubasi di dalam badan perairan selama kurang lebih tiga jam. Setelah masa inkubasi, botol winkler diambil dan diukur Gross 
Primary Productivity (GPP), Net Primary Productivity (NPP) dan Respirasi. Menurut Fahmi dan Setyono (2015), rumus yang digunakan untuk menghitung GPP,NPP dan respirasi adalah sebagai berikut.

$$
\begin{gathered}
\operatorname{GPP}(\mathrm{mgC} / \mathrm{L} / \mathrm{jam})=0,375 \frac{L B-D B}{N \times P Q} \\
N P P(\mathrm{mgC} / \mathrm{L} / \mathrm{jam})=0,375 \frac{L B-I B}{N \times P Q} \\
\text { Respirasi }(\mathrm{mgC} / \mathrm{L} / \mathrm{jam})=0,375 \frac{I B-D B}{N \times P Q} R Q
\end{gathered}
$$

Keterangan :

LB : Botol Terang (setelah inkubasi)

DB : Botol Gelap (setelah inkubasi)

IB : Kandungan O2 awal sebelum inkubasi

PQ : Phosynthesis Quotient

RQ : Respiration Quotient

$\mathrm{N}$ : Lama Inkubasi

\section{Pengamatan densitas zooxanthellae}

Menurut Nordemar et al., (2003), konsentrasi zooxanthellae dalam polip karang dipergunakan sebagai variabel utama kajian ini. Berkenaan dengan pengukuran peubah ini, maka dilakukan dengan cara mengambil sebagian spesimen karang Acropora sp (dengan luas 5 - $10 \mathrm{~cm}$ ) dari sampel permukaan polip karang. Permukaan polip karang dengan luasan yang sama dicacah pelan dengan menggunakan mortal dan alu hingga hancur dan zooxanthellae lepas. Kemudian diletakkan dalam cawan petridis dan dihomogenasi dalam $10 \mathrm{ml}$ aquadest. Kemudian dituangkan kedalam botol sampel untuk di homogenasi dengan alat centrifiuges selama 10 menit dengan kecepatan 2500 - 3000 rpm untuk memisahkan supernatannya. Selanjutnya supernatannya dianalisis dengan menggunakan haemocytometer.

Densitas zooxanthellae dapat diamati dan dihitung menggunakan haemocytometer dan rumus. Menurut Effendi (2012) rumus yang digunakan untuk menghitung jumlah sel/ml pada kotak sedang adalah sebagai berikut :

$$
\mathrm{D}=\frac{\mathrm{Q} \times \mathrm{P} \times 10000}{\mathrm{~L}}
$$

Keterangan :

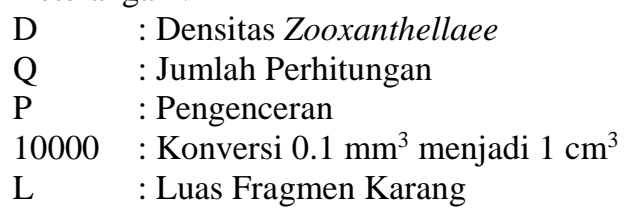

\section{Analisa Kimia Terhadap Kadar Nitrat pada Polip Karang}

Sampel karang diambil dengan ukuran 3-4 cm kemudian dimasukkan dalam coolbox dan dibawa ke laboratorium. Menurut Hutagalung dan Rozak (1997), ekstrasi sampel untuk analisis nitrat dan fosfat dengan cara sebagai berikut :

1. Preparasi sampel dilakukan dengan cara mengeringkan sampel polip karang menggunakan oven, kemudian menghaluskan karang dengan cara ditumbuk;

2. Menimbang 2 gram sampel dengan teliti dan dimasukkan ke dalam botol, kemudian ditambahkan larutan pengekstrak Bray I sebanyak $14 \mathrm{ml}$, kocok selama 1 menit. Lalu menyaring dengan kertas saring Whatman, hasil saringan siap untuk dianalisis dengan menggunakan prosedur kualitas air.

Pengukuran nitrat pada polip karang dengan cara $10 \mathrm{ml}$ sampel air limbah dimasukkan ke dalam tabung reaksi dimana sebelumnya sudah disaring dengan menggunakan kertas saring agar sampel tidak keruh. Lalu, $10 \mathrm{ml}$ sampel air limbah tersebut ditambahkan dengan $1 \mathrm{ml} \mathrm{HCl} 1 \mathrm{~N}$. Selanjutnya dikocok dan dibiarkan selama 10 menit. Warna kuning yang terjadi diukur intensitasnya dengan spektrofotometer uv-visible (Thermoscientific genesys 10S) pada panjang gelombang $220 \mathrm{~nm}$ dan $275 \mathrm{~nm}$.

\section{Analisis Data}

Pengolahan dan analisa data menggunakan perangkat lunak SPSS. Perangkat lunak SPSS ini dapat menghitung uji $\mathrm{t}$ dan korelasi pearson yang digunakan. Uji t digunakan untuk membedakan nilai setiap variabel berdasarkan kedalaman. Uji korelasi pearson digunakan untuk melihat hubungan antara tiap variabel.

\section{HASIL DAN PEMBAHASAN}

\section{A. Hasil Penelitian}

\section{Deskripsi Lokasi}

Kawasan reef flat pada stasiun I terletak di bagiun timur dari sisi pulau. Stasiun I titik 1 ini merupakan daerah hamparan karang yang rapat. Pada pulau ini tidak ditemukan dermaga untuk kapal bersandar. Jarak dari bibir pantai ke kawasan reef flat yang dijadikan stasiun I berjarak $\pm 200 \mathrm{~m}$. Pengambilan sampel karang berada pada titik S $05^{\circ} 49^{\prime} 44,2^{\prime \prime}$ dan E $110^{0} 22^{\prime} 55,2$ '. Pada Stasiun II berjarak 500m. Pengambilan sampel karang berada pada titik S $05^{\circ} 49^{\prime} 45,75^{\prime \prime}$ dan E 
$110^{\circ} 22^{\prime} 50,32^{\prime}$ 'Kondisi lapangan pada stasiun ini di dominasi oleh terumbu karang yang masih hidup serta ikan - ikan karang yang beragam. Biasanya lokasi ini dijadikan sebagai tempat para wisatawan untuk melakukan snorkeling.

\section{Kualitas Air}

Temperatur air berkisar $23-24{ }^{\circ} \mathrm{C}$. Temperatur air pada kedalaman 5 meter cenderung lebih rendah dibandingkan kedalaman 1 meter dikarenakan saat pengambilan data kondisi lingkungan sekitar mendung dan terdapat gerimis. Parameter fisika di reef flat dan kedalaman 5 meter didapatkan salinitas sebesar $31 \%$, dimana nilai tersebut tergolong normal untuk perairan laut. Hasil pengukuran oksigen terlarut (DO) 6,2 - 7,6 mg/l, nilai tersebut tergolong normal mendukung kehidupan binatang karang di laut. Derajat keasaman ( $\mathrm{pH}$ ) yang di dapatkan senilai 8 yang termasuk kondisi basa, sifat kebasaan air laut merupakan fenomena yang lazim. Kandungan nitrat perairan di dua kedalaman yang berbeda berkisar $0,176-0.279 \mathrm{mg} / \mathrm{l}$.

Tabel 1. Parameter Kualitas Perairan

\begin{tabular}{ccccccc}
\hline \multirow{2}{*}{ Stasiun } & \multirow{2}{*}{ Kedalaman } & \multicolumn{5}{c}{ Parameter Kualitas Perairan } \\
\cline { 3 - 7 } & & $\begin{array}{c}\text { Temperatur } \\
\text { Air }\end{array}$ & $\mathrm{pH}$ & Salinitas & DO (mg/l) & Nitrat (mg/l) \\
\hline I & $1 \mathrm{~m}$ & 23 & 8 & 31 & 6,8 & 0.176 \\
& $5 \mathrm{~m}$ & 23 & 8 & 31 & 6,2 & 0.176 \\
II & $1 \mathrm{~m}$ & 24 & 8 & 31 & 7,6 & 0.245 \\
& $5 \mathrm{~m}$ & 24 & 8 & 31 & 7,2 & 0.279 \\
\hline
\end{tabular}

\section{Penutupan Karang}

Penutupan terumbu karang pada kedalaman 1 meter dan 5 meter disajikan dalam tabel 2 sebagai berikut: Tabel 2. Rerata Presentase Penutupan Karang

\begin{tabular}{|c|c|c|c|c|c|}
\hline \multirow{2}{*}{ No } & \multirow{2}{*}{ Jenis Tutupan } & \multicolumn{2}{|c|}{1 meter } & \multicolumn{2}{|c|}{5 meter } \\
\hline & & $\mathrm{cm}$ & $\%$ & $\mathrm{~cm}$ & $\%$ \\
\hline 1 & Karang hidup & 2115 & 70,5 & 2305 & 76,83 \\
\hline 2 & Karang mati & 235 & 7,83 & 350 & 11,67 \\
\hline 3 & Pecahan karang & 175 & 5,83 & 315 & 10,5 \\
\hline 4 & Pasir & 475 & 15,83 & 30 & 1 \\
\hline & Jumlah & 3000 & 100 & 3000 & 100 \\
\hline
\end{tabular}

Berdasarkan hasil pengamatan didapatkan tutupan karang hidup pada kedalaman 1 meter dan 5 meter sebesar 70,5\% dan 76,83\%. Kondisi tutupan karang di Pulau Cemara Kecil ini dapat digolongkan kedalam kategori baik dan sangat baik, karena kondisi tutupan karang hidupnya yang lebih dari 50\% berdasarkan KEPMEN LH No. 4 Tahun 2001 tentang kondisi tutupan terumbu karang.

Jenis karang hidup yang ditemukan di Pulau Cemara Kecil diantaranya dari genus Acropora, Porites, Pachyseris, Leptoseris, Montipora dan beberapa jenis lainnya. Berdasarkan hasil pengamatan karang yang paling sering ditemui adalah Acropora divaricata (26,58\%) dan Porites sylindrica (40,38\%). Ciri - ciri karang dominan yang ditemukan di Pulau Cemara Kecil, Karimunjawa.

4. Analisis densitas zooxanthellae, NPP dan Nitrat

Tabel 3. Rerata Densitas Zooxanthellae pada Beberapa Jenis Karang

\begin{tabular}{|c|c|c|c|}
\hline \multirow{2}{*}{ Stasiun } & \multirow{2}{*}{ Jenis Karang } & \multicolumn{2}{|c|}{ Densitas Zooxanthellae $\left(\mathrm{sel} / \mathrm{cm}^{2}\right)$} \\
\hline & & 1 meter & 5 meter \\
\hline \multirow[t]{2}{*}{ I } & Acropora secale & $70,25 \times 10^{4}$ & $10,50 \times 10^{4}$ \\
\hline & Porites sylindrica & $37,37 \times 10^{4}$ & $12,05 \times 10^{4}$ \\
\hline \multirow[t]{2}{*}{ II } & Acropora secale & $50,53 \times 10^{4}$ & $11,27 \times 10^{4}$ \\
\hline & Porites sylindrica & $38,52 \times 10^{4}$ & $10,41 \times 10^{4}$ \\
\hline
\end{tabular}

Dapat diketahui bahwa densitas zooxanthellae pada kedalaman 1 meter atau wilayah reef flat lebih tinggi dibandingkan dengan kedalaman 5 meter. Densitas zooxanthellae karang Acropora divaricata lebih besar dibanding dengan karang Porites sylindrica, pada kedalaman 1 dan 5 meter.

Tabel 4. Analisis Produktivitas Primer pada Kedalaman 1 meter dan 5 meter $\left(\mathrm{mgC} / \mathrm{m}^{2} / \mathrm{jam}\right)$

\begin{tabular}{llcc}
\hline \multirow{2}{*}{ Stasiun } & \multicolumn{2}{c}{ Jenis Karang } & \multicolumn{2}{c}{ NPP } \\
\cline { 3 - 4 } & & 1 meter & \multicolumn{2}{c}{5 meter } \\
\hline I & Acropora divaricata & 50 & 6,25 \\
& Porites sylindrica & 62,5 & 4,17 \\
II & Acropora divaricata & 33,33 & 2,08 \\
& Porites sylindrica & 33,33 & 8,33 \\
\hline
\end{tabular}

${ }^{\circledR}$ Copyright by Management of Aquatic Resources (MAQUARES) 
Dapat diketahui bahwa nilai NPP pada kedalaman 1 meter lebih tinggi dibandingkan dengan kedalaman 5 meter. Pada Kedalaman 1 meter NPP berkisar dari 33,33-62,5 mgC/ $\mathrm{m}^{2} / \mathrm{jam}$. Pada kedalaman 5 meter NPP berkisar dari 33,33 $-37,50 \mathrm{mgC} / \mathrm{m}^{2} / \mathrm{jam}$.

Tabel 5. Hasil Analisis Konsterasi Nitrat Terhadap Polip Karang

\begin{tabular}{clrr}
\hline \multirow{2}{*}{ Stasiun } & \multicolumn{2}{c}{ Jenis Karang } & \multicolumn{2}{c}{ Kandungan Nitrat (mg/L) } \\
\cline { 3 - 4 } & & 1 meter & 5 meter \\
\hline \multirow{2}{*}{ I } & Acropora divaricata & 3,56 & 1,97 \\
& Porites sylindrica & 12,25 & 43,28 \\
\multirow{2}{*}{ II } & Acropora divaricata & 5,14 & 1,90 \\
& Porites sylindrica & 21,00 & 38,83 \\
\hline & Rata - rata & 10,49 & 21,49 \\
\hline
\end{tabular}

Berdasarkan tabel diatas dapat diketahui bahwa kandungan nitrat pada kedalaman 1 meter lebih rendah dibandingkan dengan kedalaman 5 meter. Pada kedalaman 1 meter, didapatkan konsetrasi nitrat karang Acropora divaricata berkisar 3,5 - 5,1 mg/L dan pada kedalaman 5 meter sebesar 1,9 mg/L. Pada kedalaman 5 meter, didapatkan konsetrasi nitrat karang Porites sylindrica sebesar 12,25 - $21 \mathrm{mg} / \mathrm{L}$ dan pada kedalaman 5 meter sebesar 38,83 - 43, 28 $\mathrm{mg} / \mathrm{L}$. Selain itu, konsentrasi kandungan nitrat karang Porites sylindrica lebih besar dibandingkan dengan konsentrasi pada karang Acropora divaricata pada dua kedalaman.

\section{Perbedaan Densitas Zooxanthellae, Net Primary Productivity (NPP) dan Kandungan Nitrat pada Dua} Kedalaman dengan Uji T

Tabel 6. Analisis Uji T Perbedaan Zooxanthellae, Produktivitas Primer, Respirasi dan Kandungan Nitrat pada Kedalaman $1 \mathrm{~m}$ dan $5 \mathrm{~m}$

\begin{tabular}{lrrrll}
\multicolumn{1}{c}{ Hasil Analisis } & $\mathrm{t}$ & $\mathrm{df}$ & \multicolumn{1}{c}{ Sig. (2-tailed) } & & \multicolumn{1}{c}{ Keterangan } \\
\cline { 1 - 4 } Perbedaan Zooxanthellae & 4,988 & 6 & 0,02 & signifikan \\
Perbedaan nilai NPP & 6,604 & 6 & 0,01 & signifikan \\
Perbedaan Konsentrasi Nitrat & $-0,917$ & 6 & 0,395 & tidak signfikan \\
\hline
\end{tabular}

Dimana :

H0 : Terdapat perbedaan antara variabel di kedalaman 1 meter dan 5 meter

H1: Tidak terdapat perbedaan antara variabel di kedalaman 1 meter dan 5 meter

Berdasarkan hasil anilisis uji $t$ menggunakan taraf kepercayaan 95\% ( $\alpha=0,05)$ yang dilihat dengan angka signfikansi (Sig). Untuk uji t terhadap perbedaan zooxanthellae dan NPP pada dua kedalaman, angka signifikansi yang didapatkan sebesar 0,02 dan 0,01 sehingga hipotesis yang dapat diambil adalah terima $\mathrm{H}_{0}$ tolak $\mathrm{H}_{1}$, karena terdapatnya perbedaan antara dua kedalaman. hasil analisis uji t terhadap konsentrasi nitrat terhadap kedalaman 1 meter dan 5 meter didapatkan nilai signifikansi sebesar 0,395. Sehingga hipotesis yang dapat diambil adalah tolak $\mathrm{H}_{0}$ terima $\mathrm{H}_{1}$, karena tidak terdapat perbedaan yang signifikan antara dua kedalaman.

6. Korelasi Densitas Zooxanthellae, Net Primary Productivity, dan Kandungan Nitrat pada Dua Kedalaman dengan Uji Korelasi Pearson

Tabel 7. Analisis Uji Korelasi pada Densitas Zooxanthellae, Net Primary Productivity dan Kandungan Nitrat pada Kedalaman 1 Meter

\begin{tabular}{llrrr}
\hline & & Zooxanthellae & Nitrat & NPP \\
\hline Zooxanthellae & $\mathrm{r}$ & 1 & 0,971 & 0,983 \\
\multirow{3}{*}{ Nitrat } & Sig. (2-tailed) & & 0,029 & 0,017 \\
& $\mathrm{r}$ & 0,971 & 1 & 0,982 \\
NPP & Sig. (2-tailed) & 0,029 & 0,018 \\
& $\mathrm{r}$ & 0,983 & 0,982 & 1 \\
\hline
\end{tabular}

Nilai signifikansi untuk melihat korelasi antara nitrat dan zooxanthellae pada kedalaman 1 meter sebesar 0,029 . Hal ini menunjukkan bahwa adanya korelasi antara kedua variabel tertentu karena nilai signifikansinya lebih kecil dari angka taraf kepercayaannya. hubungan antara konsentrasi nitrat dan zooxanthellae berkorelasi kuat sebesar $94 \%$. Nilai signifikansi untuk konsentrasi zooxanthellae dengan Net Primary Productivity (NPP) pada kedalaman 1 meter sebesar 0,017. Hal ini menunjukkan bahwa ada korelasi yang signifikan antara kedua variabel tersebut karena nilai signifikansinya lebih kecil dari nilai taraf kepercayaannya. Hubungan antara kedua variabel tersebut tergolong kuat. Nilai signifikansi untuk konsentrasi nitrat dengan nilai Net Primary Productivity (NPP) menunjukkan adanya korelasi yang signifikan dan hubungannya kuat. 
Tabel 8. Analisis Uji Korelasi pada Densitas Zooxanthellae, Net Primary Productivity dan Kandungan Nitrat pada Kedalaman 5 Meter

\begin{tabular}{llrrr}
\hline & & Zooxanthellae & Nitrat & NPP \\
\hline Zooxanthellae & $\mathrm{r}$ & 1 & 0,926 & 0,89 \\
\multirow{2}{*}{ Nitrat } & Sig. (2-tailed) & & 0,074 & 0,11 \\
& $\mathrm{r}$ & 0,926 & 1 & 0,869 \\
NPP & Sig. (2-tailed) & 0,074 & 0,131 \\
& $\mathrm{r}$ & 0,89 & 0,869 & 1 \\
\hline
\end{tabular}

Tidak ditemukannya korelasi yang signifikan antara kandungan nitrat dan zooxanthellae pada kedalaman 5 meter. Hubungan korelasi antara konsentrasi nitrat dan zooxanthellae pada kedalaman 5 meter tergolong kuat karena nilai koefisien korelasi yang didapat han 0,86 atau sebesar $86 \%$. Nilai signifikansi untuk konsentrasi zooxanthellae dengan Net Primary Productivity (NPP) pada kedalaman 5 meter sebesar 0,11. Hal ini menunjukkan bahwa tidak ada korelasi yang signifikan antara kedua variabel tersebut. Tidak terdapat korelasi yang signifikan antara konsentrasi nitrat dengan NPP pada kedalaman 5 meter mendapatkan karena nilai signifikansinya 0,131 lebih besar dari taraf kepercayaannya.

\section{B. Pembahasan}

Hasil pengukuran temperatur air pada lokasi penelitian di Pulau Cemara Kecil menunjukkan kisaran suhu perairan $23-24^{\circ} \mathrm{C}$, suhu tersebut tergolong kategori rendah karena kondisi lingkungan saat pengambilan data tersebut sedang hujan. Kisaran suhu ini tergolong rendah tetapi masih dapat dikategorikan normal untuk pertumbuhan karang. Menurut Nybakken (1992) bahwa pertumbuhan terumbu paling optimal terjadi di perairan yang rata - rata suhu $23-25^{\circ} \mathrm{C}$. Hasil pengukuran pH pada lokasi penelitian di Pulau Cemara Kecil bernilai 8, nilai tersebut masih tergolong normal. Menurut KEPMEN LH No. 51 Tahun 2014 menunjukan bahwa kisaran nilai pH di laut sekitar 6,5 - 8,5. Hasil pengukuran salinitas pada lokasi penelitian di Pulau Cemara Kecil bernilai 31\%o. Nilai tersebut tergolong rendah karena menurut KEPMEN LH No. 51 Tahun 2004 salinitas yang baik untuk terumbu karang bernilai 33 - 34\%o. Kadar oksigen terlarut yang didapatkan pada penlitian di Pulau Cemara Kecil berkisar 6,2 - 7,6 mg/L. Kadar oksigen terlarut masih sesuai dengan KEPMEN LH No. 51 tahun 2004 yang menyatakan kadar oksigen terlarut yang baik di laut itu lebih dari 5 mg/L. Oksigen merupakan faktor pembatas untuk kehidupan di laut karena mempengaruhi metabolisme biota. Berdasarkan hasil pengukuran kandungan nitrat pada Pulau Cemara Kecil didapatkan nilai berkisar 0,176 - 0,279 mg/L. Secara umum kandungan nitrat tersebut masih normal untuk perairan laut yang biasanya berkisar antara 0,01 - 50 mg/L. Tetapi jika dibandingkan dengan KEPMEN LH No. 51 Tahun 2014 kandungan nitrat ini tergolong tinggi karena lebih besar dari 0,08 $\mathrm{mg} / \mathrm{L}$, hal ini dikarenakan saat pengambilan data sedang turun hujan.

Berdasarkan hasil pengamatan dan data yang didapatkan bahwa densitas zooxanthellae pada karang Acropora divaricata dan Porites sylindrica pada kedalaman 1 meter dengan kedalaman 5 meter memiliki perbedaan yang signifikan. Menurut Fujise et al. (2014) bahwa hal yang memicu banyak sedikitnya zooxanthellae adalah temperatur air, intensitas cahaya serta salinitas. Barnes dan Hughes (1999) mengatakan bahwa di perairan dangkal, intesitas cahaya lebih tinggi dan menyebar secara horizontal saat masuk ke badan perairan.

Berdasarkan hasil pengukuran konsentrasi nitrat yang dilakukan, didapatkan bahwa hasil uji t, ternyata tidak terdapat perbedaan yang signifikan antara kedalaman 1 meter dengan 5 meter. Hal ini disebabkan karena semakin dalam perairan maka proses pengendapan substrat semakin tinggi. Menurut Ulqodry et al. (2010) tinggi rendahnya kandungan nitrat pada kedalaman tertentu disebabkan oleh berbagai faktor, seperti temperatur air, arus pada kedalaman tersebut dan kandungan fitoplankton, seperti zooxanthellae.

Nilai produktivitas primer bersih atau Net Primary Producitvity (NPP) kedua jenis karang pada dua kedalaman di Pulau Cemara Kecil berdasarkan hasil analisis uji t memiliki perbedaan yang signfikan. . Hal ini dikarenakan pengaruh zooxanthellae yang hidup bersimbiosis pada polip karang dan kemampuan zooxanthellae untuk memfiksasi karbondioksida yang ada di perairan. Menurut Supriharyono (2007) bahwa tinggi rendahnya produktivitas primer pada terumbu karang dipengaruhi oleh berbagai sumber lain seperti fitoplankton, lamun, mikro dan makroalga.

\section{KESIMPULAN}

Kesimpulan yang dapar diambil dari penelitian yang berjudul Pengaruh Kedalaman Terhadap Produktivitas Primer dan Densitas Zooxanthella Pada Karang Dominan di Pulau Cemara Kecil, Karimunjawa adalah sebagai berikut:

1. Densitas zooxanthellae pada polip karang di kedalaman 1 meter dan 5 meter berbeda secara signifikan; dengan dengan jumlah densitas zooxanthellae lebih tinggi pada kedalaman 1 meter $\left(37,37 \times 10^{4}-70,25 \times 10^{4}\right)$ dibandingkan dengan kedalaman 5 meter $\left(10,50 \times 10^{4}-12,05 \times 10^{4}\right)$.

2. Konsentrasi nitrat pada polip karang di kedalaman 1 meter $(3,56 \mathrm{mg} / \mathrm{l}-21 \mathrm{mg} / \mathrm{l})$ dan $5 \mathrm{~meter}(1,97 \mathrm{mg} / \mathrm{l}-43,28$ $\mathrm{mg} / \mathrm{l})$ tidak berbeda secara signfikan, hal ini dipengaruhi oleh beberapa faktor seperti arus air dan kemampuan yang berbeda pada setiap jenis karang untuk menyerap nutrien. 
3. Nilai NPP pada polip karang di kedalaman 1 meter dan 5 meter berbeda secara signifikan; dengan dengan nilai NPP lebih tinggi pada kedalaman 1 meter $\left(33,33-62,5 \mathrm{mgC} / \mathrm{m}^{2} / \mathrm{jam}\right)$ dibandingkan dengan kedalaman 5 meter $(2,08-$ $\left.8,33 \mathrm{mgC} / \mathrm{m}^{2} / \mathrm{jam}\right)$.

\section{UCAPAN TERIMAKASIH}

Penulis mengucapkan syukur dan terimakasih kepada Allah SWT yang telah memberikan rahmat dan karuniaNya sehingga penulis dapat menyelesaikan penelitian ini. Terimakasih diucapkan kepada Prof. Sutrisno Anggoro, MS dan Dr. Ir. Suryanti, M.Pi yang telah memberi masukan untuk penelitian ini, kepada pihak Balai Taman Nasional Karimunjawa yang telah memberikan izin dan segala informasi dalam penelitian ini. Serta kepada seluruh pihak yang membantu selama penelitian dan memberikan semangat untuk terselesainya penelitian ini.

\section{DAFTAR PUSTAKA}

Amin. 2009. Terumbu Karang; Aset yang Terancam (Akar Masalah dan Alternatif Solusi Penyelamatannya). Region, 1(2). $15(1): 21-26$.

Barnes, R.S.K., RN Hughes. 1999. An Introduction to Marine Ecology Third Edition. Australia. Blackwell Science Ltd.

Dahuri, R., J. Rais, S.P Ginting dan M. J. Sitepu, 2001. Pengelolaan Sumber Daya Wilayah Pesisir dan Lautan Secara Terpadu. Pradnya Paramita, Jakarta.

Effendi,H. 2012. Telaah Kualitas Air. Penerbit Kanisius, Jogjakarta.

English, S., Wilkinson, C and Baker, V. 1997. Survey Manual for Tropical Marine Resources. Australian Institute of Marine Science. Queensland, Australia. 390pp.

Fahmi dan D.E.D Setyono, 2015. Kondisi Lingkungan Pesisir dan Perairan Probolinggo, Jawa Timur. LIPI Press, Jakarta. 190hlm.

Fujise, L., H. Yamashita, G. Suzuki, K. Sasaki, L.M. Liao and K. Koike. Moderate Thermal Stress Causes Active and Immediate Expulsion of Photosynthetically Damaged Zooxanthellae (Symbiodinium) from Corals. 2014. Plos One.

Gustiani, L dan Ilahude, D. 2012. Foraminifera Bentik dalam Sedimen sebagai Indikator Kondisi Lingkungan Terumbu Karang di Perairan Pulau Cemara Besar dan Cemara Kecil, Kepulauan Karimunjawa, Jawa Tengah. Jurnal Geologi Kelautan, 10(1) : $23-37$

Hutagalung, H. P. dan A. Rozak. 1997. Metode Analisis Air Laut, Sedimen dan Biota. Buku 2. LIPI. Jakarta.

Mustofa,A. 2015. Kandungan Nitrat dan Pospat Sebagai Faktor Tingkat Kesuburan Perairan Pantai. Jurnal DISPROTEK, $6(1)$.

Nababan, S.M.P., Ruswahyuni dan Suryanti. 2015. Penutupan Karang Lunak (Soft Coral) pada Daerah Rataan dan Daerah Tubir di Pulau Cemara Kecil Kepulauan Karimun Jawa. Diponegoro Journal of Maquares, 4(3) :164 - 169.

Nordemar, J., M. Nystrom and R. Dizon. 2003. Effect of elevated seawater temperature and nitrat enrichment on the branching coral Porites cylindrica in the absence of particular food. Mar. Biol. 142 : 669-672.

Nybakken, J.W. 1992. Biologi Laut Suatu Pendekatan Ekologis. Gramedia. Jakarta.

Purnomo, P.W. 2011. [TESIS] Pengaruh Pengkayaan Zooxanthellae dari Berbagai Sumber Inang Terhadap Proses Translokasi dan Kalsifikasi Binatang Karang. Intitut Pertanian Bogor, Bogor.

Romimohtarto, K. dan S. Juwana. 2007. Biologi Laut : Ilmu Pengetahuan Tentang

Sayekti,S., E. Harpeni dan M. Muhaemin. 2017. Pengaruh Intensitas Cahaya Terhadap Kandungan Klorofil-a dan - c Zooxanthellae dari Isolat Karang Lunak Zoanthus sp.. Maspari Journal, 9(1): 61 - 68

Supriharyono. 2007. Pengelolaan Ekosistem Terumbu Karang. Penerbit Djambatan. Jakarta.

Ulqodry, T.Z., Yulisman. M Syahdan. Santoso. 2010. Karakteristik dan Sebaran Nitrat, Fosfat dan Oksigen Terlarut di Perairan Karimunjawa Jawa Tengah. Jurnal Penelitian Sains, 13(1). 